\title{
PENINGKATAN KAPASITAS MASYARAKAT DESA RINDU HATI DALAM PENGEMASAN PRODUK UNGGULAN
}

\section{CAPACITY BUILDING FOR COMMUNITY OF RINDU HATI VILLAGE IN PACKAGING SUPERIOR PRODUCTS}

\author{
Yessilia Osira $^{1,}$ Evanila Sivia $^{2,}$ Septri Widiono ${ }^{3}$ \\ ${ }^{1}$ Dosen Jurusan Kesejahteraan Sosial FISIP Universitas Bengkulu \\ ${ }^{2}$ Dosen Jurusan Teknologi Industri Pangan Fakultas Pertanian Universitas Bengkulu \\ ${ }^{3}$ Dosen Prodi Agribisnis Fakultas Pertanian Universitas Bengkulu \\ email: yosira@unib.ac.id
}

\begin{abstract}
Community capacity building is an effort to increase the ability, skills, understanding, attitudes, values, relationships, behavior, motivation, resources, and conditions that enable each individual, organization, network and wider system to carry out functions them and achieve the stated development goals from time to time. Based on this understanding, Bengkulu University through community service activities made efforts to increase the capacity of residents of Rindu Hati Village in Processing Superior Products. The method used in the activity was the socialization of a Home Industry Product (PIRT) permit and the introduction and practice of packaging superior products in the form of processed papaya foods and processed red picking coffee. The results of this activity show that there is a growing awareness that packaging superior village products and PIRT management are requirements that the products produced can be widely marketed to the community.
\end{abstract}

Keywords: capacity building, village superior products.

\section{PENDAHULUAN}

Rindu Hati merupakan suatu wilayah di Kecamatan Taba Penanjung Kabupaten Bengkulu Tengah yang mempunyai karakteristik wilayah khas pedesaan berupa hamparan persawahan, perkebunan dan perbukitan. Desa Rindu Hati berbatasan dengan Desa Tanjung Heran di sebelah utara, berbatasan dengan Kabupaten Kepahyang di sebelah timur, Kabupaten Seluma di sebelah selatan dan berbatasan dengan Desa Taba Teret di sebelah barat.

Visi menjadikan Rindu Hati sebagai "Desa Rindu Hati yang makmur, bermartabat, maju dan sejahtera, berbasiskan ekonomi pertanian, berkelanjutan dan ekowisata dengan menjaga kelestarian sumber daya alam, hutan dan air" merupakan acuan bagi Kepala Desa dan semua warga masyarakat dalam membangun Desa Rindu Hati sebagaimana tercantum dalam Rencana Pembangunan Jangka Menengah Desa Rindu Hati (RPJMD) Tahun 2016-2021.

Visi tersebut didukung oleh kondisi demografis Desa Rindu Hati yang dengan luas wilayah 1200 Ha, mempunyai penduduk 1074 jiwa terdiri dari 476 laki-laki dan 598 perempuan yang mayoritas penduduknya $82,2 \%$ kepala keluarga bekerja sebagai petani dengan produksi utama kopi, karet dan padi (RPJMD Rindu Hati tahun 2016-2021). Karenanya tidak mengherankan apabila di Rindu Hati kita menemukan kelompok tani-kelompok tani baik kelompok tani hutan dengan produksi utama kopi petik merah, kelompok tani yang mengembangkan peternakan dan perikanan serta kelompok tani wanita atau yang beranggotakan perempuan petani, yang fokus pada pengembangan ketahanan pangan keluarga. 
Produksi unggulan kopi petik merah mulai dikembangkan Desa Rindu Hati sejak tahun 2017 dan 2018. Melalui bimbingan dari Lembaga Ulayat serta Universitas Bengkulu, kini Rindu Hati bisa menyiapkan 2 sampai 3 ton pertahun. Meskipun demikian, berdasarkan wawancara dengan Kepala Desa Rindu Hati pada saat observasi, diketahui bahwa produksi unggulan kopi di Rindu Hati belum dikemas secara menarik, karena keterbatasan pengetahuan dan keterampilan kelompok tani. Disamping itu kelompok tani juga merasakan kesulitan dalam mengurus ijin terdaftar produk unggulan desa.

Selain itu, di Desa Rindu Hati juga terdapat hasil pertanian pepaya yang dikelola oleh kelompok wanita tani, dan ternyata juga belum dikemas secara baik sebagaimana produk makanan olahan yang akan dipasarkan kepada masyarakat luas.

Berdasarkan kondisi tersebut, maka Tim Pengabdian kepada Masyarakat Universitas Bengkulu, berencana menyelenggarakan kegiatan Pengembangan Kapasitas Warga Desa Rindu Hati dalam Pengemasan Produk Unggulan. Tujuan pelaksanaan kegiatan pengabdian kepada masyarakat ini adalah meningkatkan kapasitas, baik pengetahuan maupun keterampilan kelompok tani di Desa Rindu Hati dalam pengemasan produk unggulan desa. Melalui kegiatan pengabdian kepada masyarakat ini, diharapkan kelompok tani-kelompok tani di Desa Rindu Hati mempunyai kapasitas, baik pengetahuan maupun keterampilan dalam mengemas produk unggulan desa, yang akhirnya dapat meningkatkan pendapatan warga masyarakat desa dan bermuara pada peningkatan kesejahteraan hidup masyarakat Desa Rindu Hati.

\section{METODE PENGABDIAN}

Kegiatan pengabdian kepada masyarakat ini ditujukan bagi kelompok tani-kelompok tani di Desa Rindu Hati, terutama kelompok tani hutan (KTH) yang mempunyai kopi sebagai produk unggulan, dan kelompok wanita tani (KWT) sebagai wadah ibu-ibu petani yang bisa menjadi sumber daya dalam pengolahan dan pengkemasan produk unggulan desa Rindu Hati, khususnya pepaya. Secara rinci sasaran kegiatan pengabdian ini berjumlah 20 orang terdiri dari 10 orang perwakilan KTH Makmur Bersama dan 10 orang perwakilan KWT Rindu Hati.

Pelaksanaan kegiatan pengabdian masyarakat ini dilakukan melalui 2 (dua) kegiatan utama: 1) Pelatihan pengemasan produk unggulan desa, 2) Sosialisasi Pengurusan Perijinan Pangan Industri Rumah Tangga (PIRT) produk unggulan.

Secara rinci, pelakasanaan 2 kegiatan tersebut dilakukan melalui tahapan: 1) Persiapan, berisikan tentang kordinasi internal dan ekstenal Tim Pengabdian yang bertujuan untuk penyamaan persepsi, pembuatan insrumen evaluasi kegiatan, serta mengurus perijinan kegiatan. 2) Sosialisasi Kegiatan, berisikan penjelasan tentang maksud dan tujuan kegiatan kepada khalayak kelompok sasaran. 3) Pelatihan dan Introduksi Teknologi Pengemasan. Pelatihan dilakukan untuk meningkatkan kemampuan kelompok tani (masyarakat yang menjadi sasaran kegiatan ini) tentang pengemasan produk olahan kopi dan papaya sebagai produk unggulan desa Rindu Hati. 4) Monitoring dan Evaluasi. Tim Pengabdian bersama-sama kelomopk sasaran berupaya memastikan bahwa kegiatan 
dapat terlaksana sesuai dengan perencanaan, serta memastikan bahwa kegiatan yang direncanakan dapat mencapai tujuan yang telah ditentukan sebelumnya. 5) Penyusunan Laporan dan Publikasi. Tim Pengabdian melaksanakan penyusunan laporan serta mempublikasikan kegiatan yang telah dilakukan berkaitan dengan pengembangan kapasitas kelompok tani dalam pengemasan produk unggulan desa di Desa Rindu Hati.

\section{HASIL DAN PEMBAHASAN}

Mengacu pada Hardjanto (2006) yang menyebutkan bahwa peningkatan kapasitas merupakan suatu proses yang harus dilaksanakan pada individu, kelompok dan institusi atau organisasi, untuk menjamin kesinambungan organisasi melalui pencapaian tujuan dan sasaran organisasi yang bersangkutan, maka kegiatan pengabdian ini memfokuskan diri dengan sasaran oragnisasi sosial berupa kelompok tani hutan dan kelompok wanita tani di Desa Rindu Hati. Proses kegiatan peningkatan kapasitasnya meliputi:

1) Persiapan, berisikan tentang kordinasi internal dan ekstenal Tim Pengabdian yang bertujuan untuk penyamaan persepsi, pembuatan insrumen evaluasi kegiatan, serta mengurus perijinan kegiatan. Persiapan ini dilakukan oleh Tim Pengabdian sejak Bulan Juni sampai Juli tahun 2019, melalui pertemuan dan kordinasi internal maupun kordinasi eksternal dengan pemerintahan Desa Rindu Hati beserta ketua KTH Makmur Bersama dan Ketua KWT Rindu Hati. Disamping itu juga dilakukan kordinasi dengan Dinas Kesehatan Kabupaten Bengkulu Tengah untuk persiapan pelaksanaan kegiatan.

2) Sosialisasi Kegiatan. Sosialisasi dilaksanakan pada hari Kamis 22 Agustus 2019. Dalam tahap ini Tim Pengabdian menyampaikan latar belakang serta maksud dan tujuan dilaksanakannya kegiatan pengabdian kepada masyarakat Universitas Bengkulu dengan tema Pelatihan Pengemasan Produk Unggulan Desa Rindu Hati, yang didalamnya juga dilakukan sosialisasi pengurusan izin PIRT dari Dinas Kesehatan Kabupaten Bengkulu Tengah, khususnya oleh bagian Instalasi Farmasi.

3) Pelatihan dan Introduksi Teknologi Pengemasan. Dalam tahapan ini dilakukan:

a) Sosialisasi izin PIRT yang disampaikan oleh Luciana S.ST Kasie Farmasi ALKES dan PKRT dari Instalasi Farmasi Dinas Kesehatan Kabupaten Bengkulu Tengah. Pada kesempatan ini, Luciana menyampaikan pentingnya izin PIRT bagi produk-produk industry rumah tangga yang akan bersaing dipasaran. Dalam kegiatan tersebut juga disampaikan prosedur atau mekanisme pengurusan izin PIRT yang bisa dilakukan oleh industry rumah tangga yang dimiliki oleh masyarakat di Kabupaten Bengkulu Tengah. Pengemasan produk unggulan selain berfungsi melindungi produk dari kerusakan, juga berfungsi sebagai memperindah penampilan sehingga memudahkan untuk pemasarannya. Sedangkan pengurusan PIRT dimaksudkan sebagai tanda bahwa produk desa telah sesuai standar yang dibuat pemerintah untuk dipasarkan dan ddikonsumsi oleh masyarakat luas. Izin PIRT hanya diberikan kepada produk pangan olahan dengan tingkat resiko yang rendah dengan menerbitkan nomor PIRT sebanyak 15 digit (baru) dan 12 digit (lama) yang berlaku selama 5 tahun dan dapat diperpanjang untuk makanan dan minuman yang daya tahannya di 
atas 7 hari. Sedangkan makanan dan minuman yang memiliki daya tahan di bawah 7 hari termasuk golongan Layak Sehat Jasa Boga dan izin PIRT hanya berlaku 3 tahun dan dapat diperpanjang.
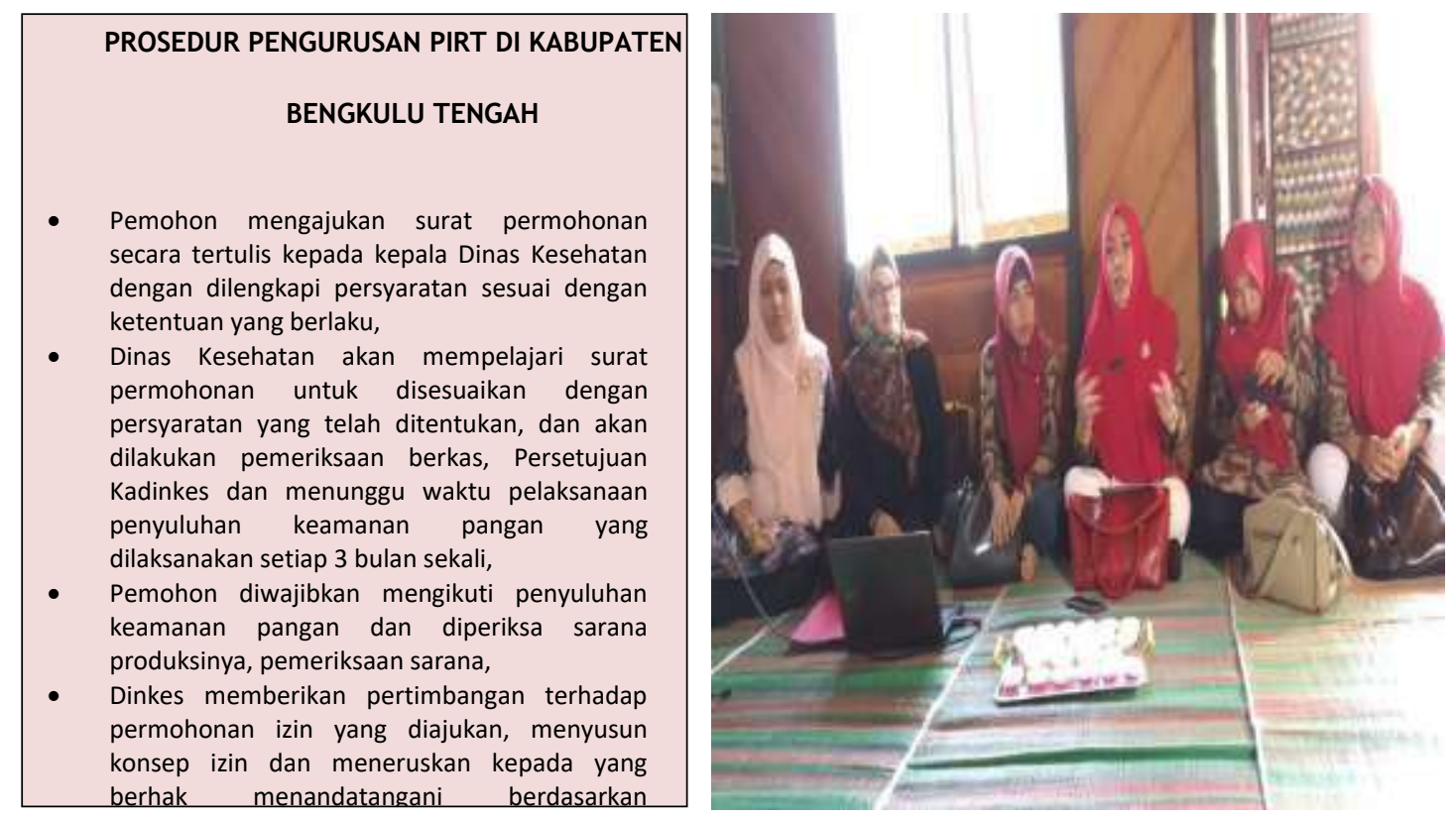

Gambar 1. Luciana SST dari Dinas Kesehatan Pemerintah Kabupaten Bengkulu Tengah sedang menjelaskan tentang izin PIRT.

b)Pelatihan dan praktek pengemasan produk unggulan desa, yang disampaiakn oleh Tim Pengabdian (Yessilia Osira, Evanila, dan Septri Widiono). Dalam kegiatan ini Tim Pengabdian menguraikan jenis-jenis pengemasan produk beserta fungsi dan tujuannya, dilanjutkan dengan praktek langsung mengkemas produk olahan kopi petik merah, produk olahan papaya seperti selai dan permen jelly dengan menggunakan peralatan yang telah diserahterimakan kepada kelompok sasaran.

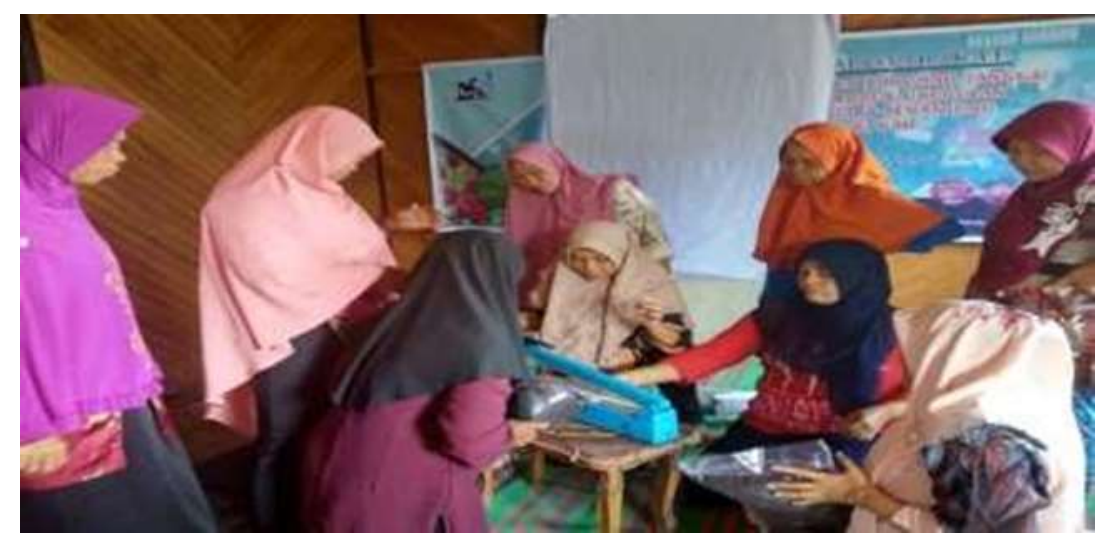

Gambar 2. Praktek pengemasan produk unggulan desa Rindu Hati dipandu oleh Tim Pengabdian

Menurut Kotler \& Keller (2009:27), pengemasan adalah kegiatan erancang dan memproduksi wadah atau bungkus sebagai sebuah produk. Pengemasan adalah aktivitas merancang dan memproduksi kemasan atau pembungkus untuk produk. Biasanya fungsi utama dari kemasan adalah untuk menjaga produk. Namun, sekarang kemasan menjadi faktor yang cukup penting sebagai alat pemasaran. (Rangkuti, 2010:132). 
Louw dan Kimber (2007) mengatakan setidaknya ada tujuh manfaat dan tujuan dibuatnya kemasan suatu produk/ barang: 1) Physical Production; Pembuatan kemasan bertujuan untuk melindungi produk/ barang dari suhu, getaran, guncangan, tekanan dan sebagainya yang ada di sekitarnya, 2) Barrier Protection; Pemasangan kemasan pada suatu produk/ barang bertujuan untuk melindunginya dari hambatan oksigen uap air, debu dan lain sebagainya, 3) Containment or Agglomeration; Pengemasan barang juga bertujuan untuk pengelompokkan sehingga proses penanganan dan transportasi menjadi lebih efisien, 4) Information Transmission; Pada kemasan juga dapat dicantumkan mengenai cara menggunakan transportasi, daur ulang, dan membuang kemasan atau label tersebut, 5) Reducing Theft; Pemasangan kemasan pada produk/ barang juga bertujuan untuk mencegah pencurian dengan melihat kerusakan fisik pada kemasan, 6) Convenience; Kemasan merupakan fitur yang menambah kenyamanan dalam distribusi, penanganan, penjualan, tampilan, pembukaan, kembali penutup, penggunaan dan digunakan kembali, dan 7) Marketing; Desain kemasan dan label dapat dimanfaatkan oleh pemasar untuk mendorong calon pembeli untuk membeli produk.

Dari kegiatan pelatihan tersebut, akhirnya didapatkan beberapa produk kemasan seperti terlihat pada gambar berikut ini:
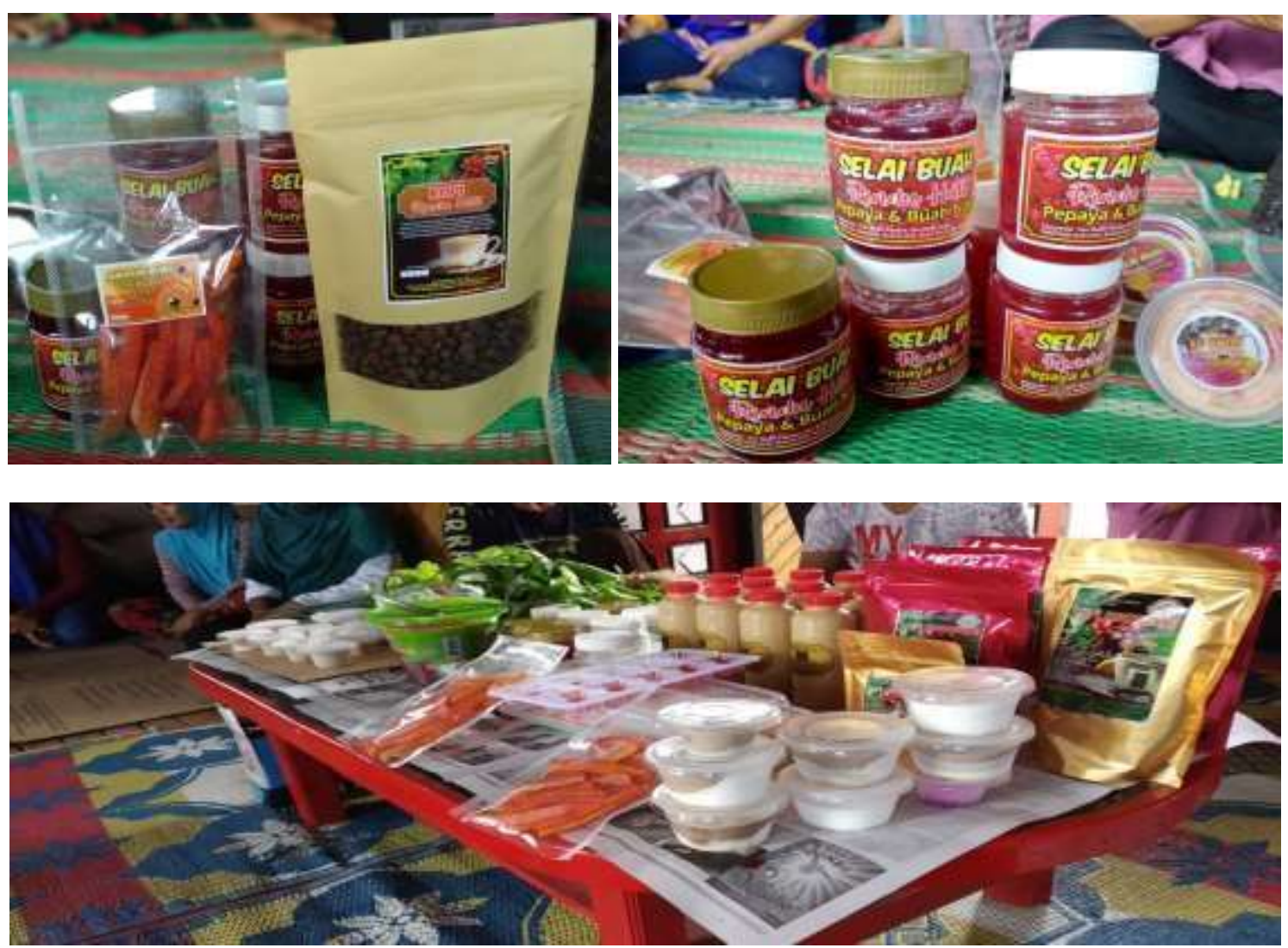

Gambar 3. Kemasan Produk Unggulan Desa Rindu Hati

4) Monitoring dan Evaluasi. Tim Pengabdian bersama-sama kelompok sasaran berupaya memastikan bahwa kegiatan dapat terlaksana sesuai dengan perencanaan, serta memastikan bahwa kegiatan yang direncanakan dapat mencapai tujuan yang telah ditentukan sebelumnya. Proses monitoring dan evaluasi pelaksanaan kegiatan ini dilakukan melalui: a) Evaluasi proses, yaitu memastikan kegiatan yang telah direncanakan dapat terlaksana dengan optimal. Kegiatan tersebut 
terdiri dari kegiatan pelatihan pengolahan produk unggulan dan sosialisasi pengurusan izin PIRT. Secara internal, kegiatan monitoring evaluasi yang dilakukan oleh Tim Pengabdian dilakukan mulai dari tahap persiapan sampai pada saat pelaksanaan kegiatan Sosialisasi Izin PIRT dan Pelatihan Pengemasan Produk Unggulan Desa Rindu Hati. Monitoring dan evaluasi diantaranya dilakukan melalui komunikasi dan kordinasi langsung dengan Kepala Desa Rindu Hati, dengan KTH Makmur Bersama, dengan KWT Rindu Hati dan juga dengan Dinas Kesehatan Kabupaten Bengkulu Tengah khususnya bagian instalasi farmasi. b) Evaluasi hasil, berkaitan dengan peningkatan pengetahuan dan ketarampilan kelompok tani dalam pengemasan produk unggulan desa, sekaligus keluarnya surat PIRT produk tersebut. Sebagai upaya peningkatan kapasitas kelompok tani, kegiatan monitoring dan evaluasi juga memastikan adanya tindak lanjut dari kelompok tani dan terutama pemerintahan DEsa Rindu Hati, untuk mengawal dan membina masyarakatnya dalam upaya membuat produk unggulan desa yang bisa dipasarkan secara luas. Hal ini sesuai dengan pendapat Morgan yang merumuskan pengertian kapasitas sebagai kemampuan, keterampilan, pemahaman, sikap, nilai-nilai, hubungan, perilaku, motivasi, sumber daya, dan kondisi-kondisi yang memungkinkan setiap individu, organisasi, jaringan kerja/ sektor, dan sistem yang lebih luas untuk melaksanakan fungsi-fungsi mereka dan mencapai tujuan pembangunan yang telah ditetapkan dari waktu ke waktu.

\section{Kesimpulan}

\section{KESIMPULAN DAN SARAN}

Berdasarkan hasil kegiatan pengabdian kepada masyarakat tentang Pelatihan Pengemasan Produk Unggulan Desa Rindu Hati, dapat disimpulkan: 1) Desa Rindu Hati memiliki beberapa produk unggulan seperti kopi petik merah yang dikelola oleh KTH Makmur Bersama, dan produk unggulan olahan buah papaya yang dikelola oleh KWT Rindu Hati. Meskipun produk tersebut sudah diolah bahkan dikemas, namun belum bisa dipasarkan secara luas karena belum teregistrasi atau belum mendapatkan izin PIRT. Berdasarkan situasi dan kondisi tersebut, Tim Pengabdian melakukan pelatihan pengemasan kopi petik merah, pengemasan es krim kopi, pengemasan hasil olahan pepaya seperti selai dan permen jelly. 2) Izin PIRT merupakan kebutuhan yang mendesak bagi upaya pemasaran produk-produk unggulan desa Rindu Hati untuk bisa dipasarkan secara luas kepada masyarakat. Oleh karena itu Tim Pengabdian bersama masyarakat Rindu Hati melaksanakan kegiatan Sosialisasi Izin PIRT yang telah dilakukan bersamaan waktunya dengan pelatihan pengemasan produk unggulan desa.

\section{Saran}

Berdasarkan permasalahan yang ditemukan selama kegiatan pengabdian kepada masyarakat ini berlangsung, Tim Pengabdian menyarankan: 1) Kepada pemerintahan Desa Rindu Hati beserta KTH dan KWT, untuk mengemas produk unggulan desa dalam bentuk kemasan yang menarik serta dilengkapi dengan izin PIRT, sehingga produk tersebut bisa dipasarkan secara luas kepada masyarakat. 2) Kepada Pemerintah Daerah Kabupaten Bengkulu Tengah, untuk mendukung penuh 
pengembangan usaha kecil dan menengah, yang salah satunya bisa dilakukan melalui penyederhanaan prosedur pengurusan izin PIRT bagi produk-produk hasil industry rumah tangga yang dihasilakn oleh masyarakat atau kelompok masyarakat di wilayah Kabupaten Bengkulu Tengah.

\section{DAFTAR PUSTAKA}

Anni Milen, 2004, Pegangan Dasar Pengembangan Kapasitas. Diterjemahkan secara bebas. Pondok Pustaka Jogja, Yogyakarta, 2004, hlm. 12

Imam Hardjanto, 2006, Pembangunan Kapasitas Lokal (Local Capacity Building). Program Pascasarjana Universitas Brawijaya, Malang, 2006, hlm 8.

Kotler dan Keller. 2009. Manajemen Pemasaran. Jilid I. Edisi ke 13. Jakarta: Erlangga.

Louw, A. \& Kimber, M, 2007, The Power of Packaging, The Customer Equity Company. Rangkuti,

Freddy. 2005. Analisis SWOT: Teknik Membedah Kasus Bisnis. Jakarta: Gramedia. Rencana Pembangunan Jangka Menengah Desa (RPJMD) Desa Rindu Hati Tahun 2016-2021. 